\title{
Notes on a Certain Trend in Portuguese Cinema
}

\author{
ANTÓNIO PRETO \\ Escola Superior Artística do Porto \\ Centro de Estudos Arnaldo Araújo
}

\begin{abstract}
The present essay examines how contemporary Portuguese cinema critically dialogues with the historical representations upon which mythical images of Portugal have been founded. Analyzing films by Manoel de Oliveira, Pedro Costa, and Miguel Gomes, the essay highlights how these filmmakers problematize, within a postcolonial perspective, the political sense of understanding modernity as a crisis of identity.
\end{abstract}

Keywords: History; identity; postcolonialism; Manoel de Oliveira; Miguel Gomes; Pedro Costa

Contemporary Portuguese cinema - let us say, over the last four decades - is haunted by Portugal's history. ${ }^{1}$ Reinventing the legacy of nineteenth-century literary Romanticism, many filmmakers have engaged in questioning the most grandiloquent representations of the country's past, whether by dismantling the hyperbolic national identity forged by the Estado Novo, or by constructively challenging those images and discourses that have attempted to break with the dictates of Salazar's historical propaganda. In both cases, it is not about opposing historical rupture to historical continuity; nor is it simply about demolishing the national mythology to erect, upon its ruins, flags of an inverted and pacifying counter-mythology that is deemed more appropriate, if not wholly acceptable and politically laundered. It is, instead, a matter of questioning the history of these representations by bringing past and present

\footnotetext{
1 This work was funded by national funds through FCT - Fundação para a Ciência e a Tecnologia, I.P., within the project UID/EAT/04041/2016.
} 
into a dialectic within which separate times overlap, reflect one another, and offer mutual commentary.

Portugal, the self-proclaimed "oldest nation in Europe," is a country dominated not by a fear of existing but rather an excess of existence (Gil). This means that national "self-knowledge," which for a long time had its main agent in literature, has led not to an identity crisis but, as Eduardo Lourenço has argued, to a problem of hyperidentity (Nós e a Europa). And, we may reasonably ask, is not cinema today assuming the status of agent once held by print literature? Centering on the irreality of the images the Portuguese gradually built of themselves over centuries, Lourenço's examination of Portuguese literature culminates in an appeal to reinvent an image with which the Portuguese might more realistically identify, given their status as citizens of a small country on the westernmost edge of Europe. The idea, as Lourenço articulares it, is to see Portugal not as "destiny" but as a "destination" that is somehow unburdened by "funereal resentments" or "pathological deliriums" (Portugal como destino 126). Lourenço argues that the time has come for Portugal to exist and to see itself in a more objective way. This argument has not fallen on deaf ears; however, it is nonetheless noteworthy that some contemporary Portuguese filmmakers seek to achieve this objective stance precisely, if paradoxically, by means of a subjectivization of history. In diverse ways, this is the case of the three films I consider in the present essay: Manoel de Oliveira's Non, ou a vã glória de mandar (1990); Miguel Gomes's Tabu (2012); and Pedro Costa's Cavalo dinheiro (2014). In each of these films, the dialectic between individual and collective emerges, against the dictates of conventional history, as a critical image.

The first aspect shared by all three films is the conception of death as an obligatory starting point. In Non, Lieutenant Cabrita - a trans-temporal personification of the history of Portugal itself and, in the film, the narrator of that history-must die for the new narrative to begin. Note that it is Oliveira's voice that suggestively announces the narrator-lieutenant's death, occurring precisely on the morning of 25 April 1974, "no dia da revolução." It is also he who, at the end of Palavra e utopia (2000), brings to the dying Father António Vieira the Papal bull that restores to him the "voz activa e passiva" of which he had been unfairly deprived. In this way, Oliveira works to bury myth and its principal agents - conferring upon the latter a salvific death that returns both 
historical images and characters to a more concrete and human plane. It is important also to bear in mind that Non only goes as far as 25 April 1974, an end that points toward a future that even as late as 1990 was still undetermined. For Oliveira, that is, the 1974 revolution did not solely represent the end of a certain form of patriotic grandiloquence; rather, it also bore the redeeming negativity of serving as an opening to a new and unscripted beginning. To die only to be reborn is already central theme of Oliveira's earlier films, such as Acto da primavera (1962), and one can see in Non a kind of Acto da primavera of Portuguese history. It is true, after all, that Lieutenant Cabrita must die (along with all the historical narratives he carries and everything he symbolizes), but he must do so in the morning.

A similarly paradoxical closeness between death, narrative, and history structures Gomes's Tabu. In this case, it is the death of the central character that allows the narrator of the second part of the film to tell her story. Death frees history and opens the possibility of its telling. Approaching her end, Aurora writes the name of her former lover, Ventura, on the hand of Santa, her African maid. The imminence of death drives Aurora to the past, but the letters she draws on the hand of her maid do not solely evoke colonial recollections: alluding to the memories of her life in Africa, where she met Ventura, her gestures become evocatively confused with those of divinatory practices like palmistry. While the film is not concerned with predicting the future (Aurora has no future, and Ventura will not arrive in time to see her before she dies), the distant past that suddenly haunts the dying Aurora nonetheless invades the present and also insinuates itself into what will come. One might recall Teixeira de Pascoaes's famous aphorism, so often cited by Lourenço: "o futuro é a aurora do passado." What is essential to highlight, however, is that Aurora's death in Tabu, which takes place just before the coming of the new year, establishes an inversion between beginning and end that is not far from Lieutenant Cabrita's morning death in Oliveira's Non.

In Non and Tabu, one finds a ghost story haunted by the ghosts of history such as those which Jacques Rancière identifies in Costa's Cavalo dinheiro. Rancière argues that Costa "has sided with the ghosts, with a kind of story in which the dead come to try the living" (88). In this film, Costa follows the Fontaínhas neighborhood and the move of the Cape Verdeans who used to live there to public housing, a move that corresponds neither to a transition from an 
area of shade to the light of day nor to the turning of a new blank page ready to receive the rewritten life story of these marginal figures. Costa instead returns to what he terms a "Baudelairean night" (Peranson), where "the sky, low and heavy, weighs like a lid on the groaning / spirit, prey to long ennui" (Baudelaire 100). While Juventude em marcha (2006) deals with "making a body move through different places that form a possible topography of our geographic, economic and cultural world" (Rancière 88), almost everything in Cavalo dinheiro takes place in a hospital, a locus that acquires a dual conceptual status in the film: a place of healing but also, perhaps above all, a place of death. Hospitals make an appearance in Costa's earlier films, such as Ossos (1997), No quarto de Vanda (2000), and Juventude em marcha. In these films, the characters are stigmatized and shut away in their rooms, already prisoners to the disease projected upon them. They are isolated from the world. Unlike Non and Tabu, which also feature decisive hospital scenes, Cavalo dinheiro does not present the hospital as a place of passage between an end and a starting-again. That is, the hospital in Cavalo dinheiro is not a place of healing; it is rather an institution that takes no responsibility for Ventura except to remove him from the light of day, to enclose him within the catacombs of invisibility. The hospital (and Ventura's striped pajamas leave no room for doubt) appears as a death camp that radicalizes dispossession: dispossession of space and time, dispossession of history, dispossession of oneself; all in all, it mediates the reduction to nothingness of a character deprived of existence.

How do Non, Tabu, and Cavalo dinheiro link up time, memory and history? Oliveira sketches out the trans-temporal portrait of a people, a polyptych that attempts to rethink the history of Portugal- not from its epic feats but from its defeats. It is worth considering here that the historical storytelling of Lieutenant Cabrita takes place in the context of the Portuguese colonial wars and that the battles he evokes are largely recreated in the film by the same actors who play both his comrades-in-arms and audience. The blood pumping through these soldiers' veins, one might say, is the blood that gives life to all history (likewise the blood shed in the battles retold by Cabrita). The film also questions the mythical blood ties that traditionally enable one to think about national identity in the first place. Accepting the hypothesis put forward in the film's final sequence, according to which there is a "blood relation" between D. Sebastião's imperialist dream and the colonial war in which the 
lieutenant and his comrades take part, Non is a kind of cinematographic tomb of the unknown soldier for all battles and all times. It is also this blood relation (and ideological sequence) that the lieutenant viscerally vomits and rejects: not another word will come from his mouth (end of story) - only the purgation of poisoned blood can open up to a history yet to be written, a history for which he is responsible but to which he does not belong. The story that Oliveira tells takes place in the present indicative: it develops at a midpoint between past and present in a past-present that makes of Non a tomb for official history.

For Gomes, the present is the lost paradise from which to access the paradise of the colonial past. In the first part of Tabu, which takes place in contemporary Lisbon, many details allude to the survival of the colonial past, which is fully recalled in the film's second part. ${ }^{2}$ The lush vegetation decorating Aurora's apartment, the palm trees and the giraffe in Parque das Nações, the plastic tropical plants in the shopping center (where the characters have coffee) and, even more so, the film Pilar watches in the prologue about the adventurous nineteenth-century explorer, are some of the clues pointing to the ghosts of Africa. Except for Aurora's death, the entire first part of the film unfolds without any major events: the characters live in a state of melancholy and express a desire for fiction that the second part, corresponding to Aurora's life in Africa, will fulfill. The African past emerges as a funfair filled with adventures and romantic invitations, and Aurora's personal story is interwoven into the history of the colony. Gomes allows himself the poetic license (a fictional hypothesis not always understood in the best way) to propose that the fight for independence was set off by an amorous conflict with Aurora at the center. Aurora thus appears as an involuntary historical agent: she is responsible for the war, just as she is responsible for the unhappiness, spleen, and feeling of loss that characterize the first part of the film.

Cavalo dinheiro takes place, as Costa suggests, in an "eternal present" (Peranson). No story is possible here, since the matter of the film-Ventura's traumatic memories, his dreams and his nightmares - does not allow itself to be organized into a coherent discourse. The matter is sparse, and time is suspended

\footnotetext{
2 The film's title is itself an intertextual reference to Friedrich Wilhelm Murnau's film of the same name, a film with which Gomes establishes an inverted reflection. It is also an evocation of the subjective, politically disturbing memory of what was, for many former Portuguese settlers, the colonial experience.
} 
in a fixed movement that resembles the film's elevator sequence. In this scene, we realize the elevator is working, but we don't know whether it is going up or down: it is, in a sense, paralyzed or suspended in its own movement. Ventura, who stares at the camera with spectral immobility, finds himself possessed by the history that has left him out. He lived through the 1974 revolution and took part in building a democratic Portugal (quite literally, in fact, since he was a construction worker). At the same time, however, he is subjected to a paradoxical condition in that he is neither with the winners nor the losers. He belongs instead to a third category, one that lies outside any historical or political discourse and groups together all those who are and must remain invisible, since their mere existence contradicts the very foundations of the regime they helped to erect. In a word, Ventura is a ghost. He embodies a taboo that political correctness forbids the Portuguese to face, and he stands on the opposite side of both the history of military defeat recounted in Non and the view of the colonial period as a happy experience in Tabu. Costa has stated recently that he came to learn that as a teenager, Ventura used to hide from view with other African workers behind the trees in the Jardim da Estrela (Peranson). His wish was to disappear, to remove himself from view, to become invisible. He did not understand what was going on, but he knew that it did not ultimately concern him. Ventura is thus forgotten by the history he himself wishes to forget. He is not possessed by the ghosts of history (since he is himself a specter); rather, he is possessed by a ghost story, a story with no history, no way out, no images, a story that threatens to swallow him up into the biggest and most convenient of invisibilities.

Costa's work is, ultimately, to make visible what cannot be seen. As a filmmaker, he is possessed by films, by John Ford, Jacques Tourneur, Fritz Lang, even as Ventura is possessed by his own demons and memories. In this sense, Cavalo dinheiro is a kind spiritualist ritual, a work about this form of double possession, a ghost ritual that begins with the wraiths of colonialism (as in Jean Rouch's films) as well as an exorcism of history, of Ventura's life and what he wishes to bury, and of Costa's cinematographic and literary references. While Oliveira prefers to remain on the level of literality concerning his documentary sources and the (theatrical) objectivity of the acting, Gomes and Costa are interested in a more expressionist aesthetic, a projection of the inner world of the characters into a deformed and transformed space fashioned into a 
mental landscape. In a film as dark as Cavalo dinheiro, everything can enter and exit, forging a game of shadows that presents itself as oneiric theater.

The scene in Cavalo dinheiro that best presents Ventura's mental world is the elevator sequence. It exists and does not exist; linked to the film's dominant tenebrism, it makes one think of Francisco Goya. In one of his Caprichos, Goya portrays a coco, a monstrous figure as real as the ghost seen by Hamlet. Like the coco, the MFA soldier in the lift next to Ventura resembles a ghostly figure such as those often used to make children do as they are told. As Clément Rosset proposes, "the guardians of sleep summoned as a last resort to put a restless child to sleep still act in a violent way: first they disturb, then they kill and devour like ogres" (61). According to Rosset, one of the virtues characteristic of Goya's art is his ability to "portray the unimaginable, the inexistent, doing it as realistically as possible" (65-67). This realism should be understood as "a way of showing that a certain object or scene exists and at the same time does not exist or, at least, only exists in the imagination. . . . There are often two distinct planes in Goya's prints or paintings, in a way, two places of reality: one for existence and the other for the imagination, and the miracle is these two planes coincide" (65-67). Rosset finally concludes that "the most curious thing of all is not, by the way, the figure (or size) of the apparition, but the apparition itself, the very fact that it appears" (68).

Going back to the elevator scene in Cavalo dinheiro, the apparition of the soldier's glorious body is not only massive but, above all, metallic: it is like a bronze statue that monumentalizes Ventura's fear while concomitantly materializing the memory of the revolution. We do not know, in this case, whether statues also die. We do not know whether this soldier is Ventura's enemy or protector; whether he is the one who keeps him in prison or, on the contrary, the one who will finally set him free. He is, in any case, a solid image. He possesses a density that not even the sudden intervention of music (in this case, a new "apparition" in the form of L'apparition de l'église éternelle by Olivier Messianen) can disturb. The clash between this intermezzo and what Ventura sings next, "Alto cutelo" by the Cape Verdean group Os Tubarões, is clear. On one side, one hears the desire for eternity corresponding to the dominant doxa, and on the other, singing to forget as Ventura does.

Costa's filme de morte-vivo delves deeply into memory to reach oblivion. As he explains, Ventura "really is sick and ill and he really tries to remember, 
and trying to remember is not the best thing. So I think we did this film to forget, actually. Some people say they make films to remember, I think we make films to forget. This is really to forget, to be over with" (Peranson). Ventura's disease appears to be history experienced as insomnia. He cannot fall asleep. In Juventude em marcha, there is a scene in which Lento, an illiterate character, asks Ventura to write a love letter that he might send to his girlfriend in Cape Verde. As there is no pen in the shack where they live, it is impossible to write. For this reason, Ventura must keep the letter in his memory, to learn it by heart. Filming with these men and women - one only speaks of "characters" for the sake of convenience-Costa becomes a kind of public writer: he must write his stories cinematographically, give a kind of image to invisibility, and then make that image disappear. The paradox lies in the fact that it is not actually possible to make something disappear that has not yet appeared.

It is true that the people who lived through Portuguese colonialism are gradually disappearing, and cinema has a duty - in spite of everything - to remember, to provide an image to the ghosts of this story so that one can see them, meet them, and bury them in the living cemetery that is history. Cinema, as Alain Resnais and Chris Marker suggest at the beginning of their 1953 film, Les statues meurent aussi (Statues also die), is an agent of the botany of death we refer to as culture. The questions raised today by a cinema that intends to be political cannot overlook the need to re-establish a relationship between politicity and efficacy, as Rancière rightly observes (88). It is perhaps through the critical subjectification of historical representations (of the representations of history and the history of those representations) that we may come to build a suitable image of Portugal for its historical and present reality, a condition that cannot be objectively fulfilled, because images (like statues) also die. To achieve this, we must remember those who were systematically forgotten by history. Why is this so? Precisely so that those forgotten by history may come to forget it. To do otherwise is to invite the return of a mortal oblivion, carried by the residue of images and buried in history as a chronic disease.

\section{Works Cited}

Baudelaire, Charles. The Flowers of Evil, translated by Keith Waldrop, Wesleyan UP, 2006. 
Costa, Pedro, director. Cavalo dinheiro. Sociedade Óptica Técnica, 2014.

—. Juventude em marcha. Contracosta Produções, 2006.

- No quarto de Vanda. Contracosta Produções, 2000.

—. Ossos. Madragoa, 1997.

Gil, José. Hoje: o medo de existir. Relógio d'Água, 2004.

Gomes, Miguel, director. Tabu. O Som e a Fúria, 2012.

Lourenço, Eduardo. Nós e a Europa: ou as duas razões. Imprensa NacionalCasa da Moeda, 1994.

—. O labirinto da saudade: psicanálise mítica do destino português. Dom Quixote, 1982.

- Portugal como destino, seguido de mitologia da saudade, Gradiva, 1999.

Oliveira, Manoel de, director. Acto da primavera, Lusomundo, 1962.

-. Non, ou a vã glória de mandar, Madragoa, 1990.

—. Palavra e utopia, Madragoa, 2000.

—. "Tentative pour expliquer l'inexplicable." Trafic, no. 8, 1993, pp. 135-42.

Os Tubarões. “Alto Cutelo.” Pepe Lopi, Zé Orlando, 2010.

Peranson, Mark. "L'avventura: Pedro Costa and Horse Money." Cinema Scope, no. 60, 2014, www.cinema-scope.com/cinema-scope-magazine/tiff-2014horse-money-pedro-costa-portugal-wavelengths/. Accessed 3 April 2017.

Rancière, Jacques. "Le reste, c'est à vous de l'inventer." Cahiers du Cinéma, no. 709, 2015, pp. 84-94.

Resnais, Alain, and Chris Marker, directors. Les statues meurent aussi, TadiéCinéma, 1953.

Rosset, Clément. L'Invisible. Minuit, 2012. 